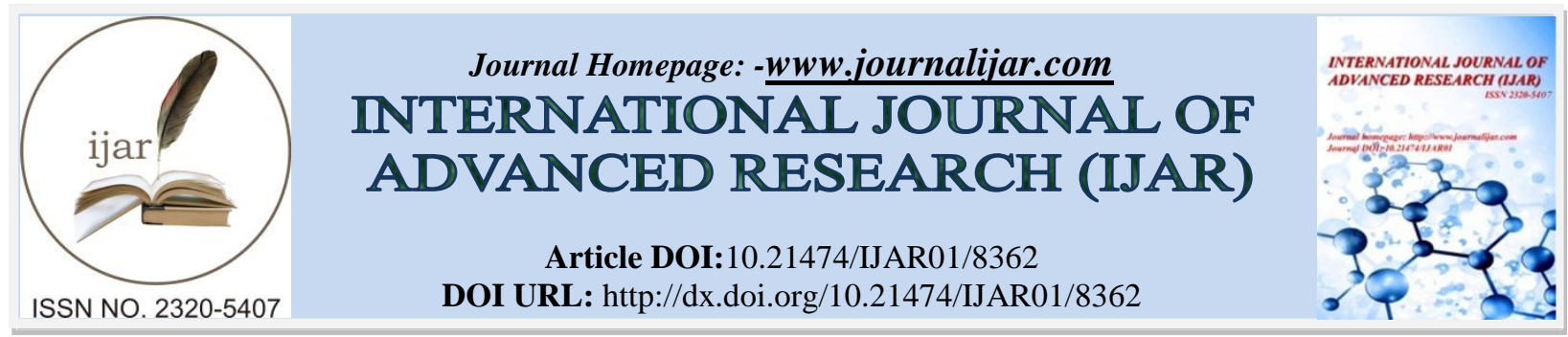

RESEARCH ARTICLE

\title{
FACTORS AFFECTING CONSUMER BUYING BEHAVIOUR.
}

Chandan. A.

Mba, net.,planning executive in aquarelle india pvt ltd (textile company).

\section{Manuscript Info}

Manuscript History

Received: 08 November 2018

Final Accepted: 10 December 2018

Published: January 2019

\begin{abstract}
Consumer Buying Behaviour refers to the buying behaviour of the ultimate consumer. Many factors, specificities and characteristics influence the individual in what he is and the consumer in his decision making process, shopping habits, purchasing behaviour, the brands he buys or the retailers he goes. A purchase decision is the result of each and every one of these factors. An individual and a consumer is led by his culture, his subculture, his social class, his membership groups, his family, his personality, his psychological factors, etc. and is influenced by cultural trends as well as his social and societal environment. By identifying and understanding the factors that influence their customers, brands have the opportunity to develop a strategy, a marketing message (Unique Value Proposition) and advertising campaigns more efficient and more in line with the needs and ways of thinking of their target consumers, a real asset to better meet the needs of its customers and increase sales.
\end{abstract}

Copy Right, IJAR, 2017,. All rights reserved.

\section{Introduction:-}

Consumer buying behaviour refers to the selection, purchase and consumption of goods and services for the satisfaction of their wants. There are different processes involved in the consumer behaviour. Many factors, specificities and characteristics influence the individual in what he is and the consumer in his decision making process, shopping habits, purchasing behaviour, the brands he buys or the retailers he goes. A purchase decision is the result of each and every one of these factors. Initially the consumer tries to find what commodities he would like to consume, then he selects only those commodities that promise greater utility. After selecting the commodities, the consumer makes an estimate of the available money which he can spend. Lastly, the consumer analyses the prevailing prices of commodities and takes the decision about the commodities he should consume. Meanwhile, there are various other factors influencing the purchases of consumer such as social, cultural, economic, personal and psychological.

\section{Factors Influencing Consumer Buying Behaviour:-}

The consumer behaviour or buyer behaviour is influenced by several factors or forces. They are:

1. Internal or Psychological factors

2. Social factors

3. Cultural factors

4. Economic factors

5. Personal factors.

\section{Corresponding Author:-Chandan.A.}

Address:-Mba, net.,planning executive in aquarelle india pvt ltd (textile company). 
There are five questions that support any understanding of consumer behaviour.

1. Who is the market and what is the extent of their power with regard to the organisation?

2. What do they buy?

3. Why do they buy?

4. Who is involved in the buying?

5. How do they buy?

6. When do they buy?

7. Where do they buy?

The answers of these questions provide the understanding of the ways in which buyers are most likely to respond to marketing stimuli.

\section{Internal or psychological factors:-}

The buying behaviour of consumers is influenced by a number of internal or psychological factors. The most important ones Motivation and Perception.

\section{Motivation:-}

In the words of William J Stanton, "A motive can be defined as a drive or an urge for which an individual seeks satisfaction. It becomes a buying motive when the individual seeks satisfaction through the purchase of something". A motive is an inner urge (or need) that moves a person to take purchase action to satisfy two kinds of wants viz. core wants and secondary wants.

So, motivation is the force that activates goal-oriented behaviour. Motivation acts as a driving force that impels an individual to take action to satisfy his needs. So it becomes one of the internal factors influencing consumer behaviour.

A need becomes a motive when it is aroused to a sufficient level of intensity. A motive is a need that is sufficiently pressing to drive the person to act. There can be of types of needs.

\section{Biogenic needs:-}

They arise from physiological states of tension such as thirst, hunger

\section{Psychogenic needs:-}

They arise from psychological states of tension such as needs for recognition, esteem

\section{Perception:-}

Human beings have considerably more than five senses. Apart from the basic five (touch, taste, smell, sight, hearing) there are senses of direction, the sense of balance, a clear knowledge of which way is down, and so forth. Each sense is feeding information to the brain constantly, and the amount of information being collected would seriously overload the system if one took it all in. The brain therefore selects from the environment around the individual and cuts out the extraneous noise. Therefore, the information entering the brain does not provide a complete view of the world around you. When the individual constructs a world-view, she then assembles the remaining information to map what is happening in the outside world. Any gaps (and there will, of course, be plenty of these) will be filled in with imagination and experience. The cognitive map is therefore not a 'photograph'; it is a construct of the imagination. This mapping will be affected by the following factors:

\section{Subjectivity:-}

This is the existing world-view within the individual, and is unique to that individual.

\section{Categorisation:-}

This is the 'pigeonholing' of information, and the prejudging of events and products. This can happen through a process known as chunking, whereby the individual organises information into chunks of related items. For example, a picture seen while a particular piece of music is playing might be chunked as one item in the memory, so that sight of the picture evokes the music and vice versa. 


\section{Selectivity:-}

This is the degree to which the brain is selecting from the environment. It is a function of how much is going on around the individual, and also of how selective (concentrated) the individual is on the current task. Selectivity is also subjective: some people are a great deal more selective than others.

\section{Expectation:-}

These lead individuals to interpret later information in a specific way. For example, look at this series of numbers and letters.

\section{Past experience:-}

This leads us to interpret later experience in the light of what we already know. Psychologists call this the law of primacy, sometimes sights, smells or sounds from our past will trigger off inappropriate responses: the smell of bread baking may recall a village bakery from twenty years ago, but in fact the smell could have been artificially generated by an aerosol spray near the supermarket bread counter. An example of cognitive mapping as applied to perception of product quality might run as follows. The consumer uses the input selector to select clues and assign values to them. For quality, the cues are typically price, brand name and retailer name. There are strong positive relationships between price and quality in most consumers' perceptions, and brand name and quality; although the retailer name is less significant, it still carries some weight.

\section{Social factors:-}

Man is a social animal. Hence, our behaviour patterns, likes and dislikes are influenced by the people around us to a great extent. We always seek confirmation from the people around us and seldom do things that are not socially acceptable. The social factors influencing consumer behaviour are a) Family, b) Reference Groups, c) Roles and status.

\section{Family:-}

There are two types of families in the buyer's life viz. nuclear family and Joint family. Nuclear family is that where the family size is small and individuals have higher liberty to take decisions whereas in joint families, the family size is large and group decision-making gets more preference than individual. Family members can strongly influence the buyer behaviour, particularly in the Indian contest. The tastes, likes, dislikes, life styles etc. of the members are rooted in the family buying behaviour.

The family influence on the buying behaviour of a member may be found in two ways:-

1. The family influence on the individual personality, characteristics, attitudes and evaluation criteria and

2. The influence on the decision-making process involved in the purchase of goods and services. In India, the head of the family may alone or jointly with his wife decides the purchase. So marketers should study the role and the relative influence of the husband, wife and children in the purchase of goods and services.

\section{An individual normally lives through two families:- Family of orientation:-}

This is the family in which a person takes birth. The influences of parents and individual's upbringing have a strong effect on the buying habits. For instance, an individual coming form an orthodox Tamil or Gujarati vegetarian family may not consume meat or egg even though she may appreciate its nutritional values.

\section{Family of procreation:-}

This is the family formed by an individual with his or her spouse and children. Normally, after marriage, an individual's purchasing habits and priorities change under the influence of spouse. As the marriage gets older, the people usually settle in certain roles. For instance, a father normally takes decisions on investment whereas the mother takes decision on health of children. From a marketing viewpoint, the level of demand for many products is dictated more by the number of households than by the number of families. The relevance of families to marketing is therefore much more about consumer behaviour than about consumer demand levels.

\section{Reference group:-}

A group is two or more persons who share a set of norms and whose relationship makes their behaviour interdependent. A reference group is a group of people with whom an individual associate. It is a group of people 
who strongly influence a person's attitudes values and behaviour directly or indirectly. Reference groups fall into many possible grouping, which are not necessarily to be exhaustive (i.e. non over-lapping).

\section{Roles and status:-}

A person participates in many groups like family, clubs, and organizations. The person's position in each group can be defined in tern of role and status. A role consists of the activities that a person is expected to perform. Each role carries a status. People choose products that communicate their role and status in society. Marketers must be aware of the status symbol potential of products and brands.

\section{Cultural factors:-}

Kotler observed that human behaviour is largely the result of a learning process and as such individuals grow up learning a set of values, perceptions, preferences and behaviour patterns as the result of socialisation both within the family and a series of other key institutions. From this we develop a set of values, which determine and drive behavioural patterns to a very large extent. According to Schiffman and Kanuk, values include achievement, success, efficiency, progress, material comfort, practicality, individualism, freedom, humanitarianism, youthfulness and practicality. This broad set of values is then influenced by the subcultures like nationality groups, religious groups, racial groups and geographical areas, all of which exhibit degrees of difference in ethnic taste, cultural preferences, taboos, attitudes and lifestyle. Cultural factors consist of a) Culture, b) Sub culture and c) Social class.

\section{Culture:-}

Culture is the most fundamental determinant of a person's want and behaviour. The growing child acquires a set of values, perception preferences and behaviours through his or her family and other key institutions. Culture influences considerably the pattern of consumption and the pattern of decision-making. Marketers have to explore the cultural forces and have to frame marketing strategies for each category of culture separately to push up the sales of their products or services. But culture is not permanent and changes gradually and such changes are progressively assimilated within society. Culture is a set of beliefs and values that are shared by most people within a group. The groupings considered under culture are usually relatively large, but at least in theory a culture can be shared by a few people. Culture is passed on from one group member to another, and in particular is usually passed down from one generation to the next; it is learned, and is therefore both subjective and arbitrary. For example, food is strongly linked to culture. While fish is regarded as a delicacy in Bengal, and the Bengalis boast of several hundred different varieties, in Gujarat. Rajasthan or Tamil Nadu, fish is regarded as mostly unacceptable food item. These differences in tastes are explained by the culture rather than by some random differences in taste between individuals; the behaviours are shared by people from a particular cultural background. Culture can change over a period of time, although such changes tend to be slow, since culture is deeply built into people's behaviour. From a marketing viewpoint, therefore, it is probably much easier to work within a given culture than to try to change it.

\section{Sub-Culture:-}

Each culture consists of smaller sub-cultures that provide more specific identification and socialisation for their members. Sub-culture refers to a set of beliefs shared by a subgroup of the main culture, which include nationalities, religions, racial groups and geographic regions. Many subcultures make up important market segments and marketers have to design products and marketing programs tailored to their needs. Although this subgroup will share most of the beliefs of the main culture, they share among themselves another set of beliefs, which may be at odds with those held by the main group. For example, Indians are normally seen as orthodox, conservative people, but rich, up-market youths do not hesitate to enjoy night parties with liquor and women.

\section{Social class:-}

Consumer behaviour is determined by the social class to which they belong. The classification of socioeconomic groups is known as Socio-Economic Classification (SEC). Social class is relatively a permanent and ordered division in a society whose members share similar value, interest and behaviour. Social class is not determined by a single factor, such as income but it is measured as a combination of various factors, such as income, occupation, education, authority, power, property, ownership, life styles, consumption, pattern etc. There are three different social classes in our society. They are upper class, middle class and lower class. These three social classes differ in their buying behaviour. Upper class consumers want high-class goods to maintain their status inthe society. Middle class consumers purchase carefully and collect information to compare different producers in the same line and lower class consumers buy on impulse. Therefore, marketing managers are required to study carefully the 
relationship between social classes and their consumption pattern and take appropriate measures to appeal to the people of those social classes for whom them products are meant.

\section{Economic Factors:-}

Consumer behaviour is influenced largely by economic factors. Economic factors that influence consumer behaviour are:-

1. Personal Income,

2. Family income,

3. Income expectations,

4. Savings,

5. Liquid assets of the Consumer,

6. Consumer credit,

7. Other economic factors.

\section{Personal Income:-}

The personal income of a person is determinant of his buying behaviour. The gross personal income of a person consists of disposable income and discretionary income. The disposable personal income refers to the actual income (i.e. money balance) remaining at the disposal of a person after deducting taxes and compulsorily deductible items from the gross income. An increase in the disposable income leads to an increase in the expenditure on various items. A fall in the disposable income, on the other hand, leads to a fall in the expenditure on various items. The discretionary personal income refers to the balance remaining after meeting basic necessaries of life. This income is available for the purchase of shopping goods, durable goods and luxuries. An increase in the discretionary income leads to an increase in the expenditure on shopping goods, luxuries etc. which improves the standard of living of a person.

\section{Family income:-}

Family income refers to the aggregate income of all the members of a family. Family income influences the buying behaviour of the family. The surplus family income, remaining after the expenditure on the basic needs of the family, is made available for buying shopping goods, durables and luxuries.

\section{Income Expectations:-}

Income expectations are one of the important determinants of the buying behaviour of an individual. If he expects any increase in his income, he is tempted to spend more on shopping goods, durable goods and luxuries. On the other hand, if he expects any fall in his future income, he will curtail his expenditure on comforts and luxuries and restrict his expenditure to bare necessities.

\section{Savings:-}

Savings also influence the buying behaviour of an individual. A change in the amount of savings leads to a change in the expenditure of an individual. If a person decides to save more out of his present income, he will spend less on comforts and luxuries.

\section{Liquid assets:-}

Liquid assets refer to those assets, which can be converted into cash quickly without any loss. Liquid assets include cash in hand, bank balance, marketable securities etc. If an individual has more liquid assets, he goes in for buying comforts and luxuries. On the other hand, if he has less liquid assets, he cannot spend more on buying comforts and luxuries.

\section{Consumer credit:-}

Consumer credit refers to the credit facility available to the consumers desirous of purchasing durable comforts and luxuries. It is made available by the sellers, either directly or indirect y through banks and other financial institutions. Hire purchase, instalment purchase, direct bank loans etc. are the ways by which credit is made available to the consumers. Consumer credit influences consumer behaviour. If more consumer credit is available on liberal terms, expenditure on comforts and luxuries increases, as it induces consumers to purchase these goods, and raise their living standard. 


\section{Other economic factor:-}

Other economic factors like business cycles, inflation, etc. also influence the consumer behaviour.

\section{Personal factor:-}

Personal factors also influence buyer behaviour. The important personal factors, which influence buyer behaviour, are:-

1. Age,

2. Occupation,

3. Income and

4. Life Style

Age:-

Age of a person is one of the important personal factors influencing buyer behaviour. People buy different products at their different stages of cycle. Their taste, preference, etc also change with change in life cycle.

\section{Occupation:-}

Occupation or profession of a person influences his buying behaviour. The life styles and buying considerations and decisions differ widely according to the nature of the occupation. For instance, the buying of a doctor can be easily differentiated from that of a lawyer, teacher, clerk businessman, landlord, etc. So, the marketing managers have to design different marketing strategies suit the buying motives of different occupational groups.

\section{Income:-}

Income level of people is another factor which can exert influence in shaping the consumption pattern. Income is an important source of purchasing power. So, buying pattern of people differs with different levels of income.

\section{Life Style:-}

Life style to a person's pattern or way of living as expressed in his activity, interests and opinions that portrays the "whole person" interacting with the environment. Marketing managers have to design different marketing strategies to suit the life styles of the consumers.

\section{Conclusion:-}

For a successful consumer oriented market service provider should work as psychologist to procure consumers. Bykeeping in mind affecting factors things can be made favourable and goal of consumer satisfaction can be achieved. Study of consumer buying behaviour is gate wayto success in market.

\section{References:-}

1. Consumer Behavior. Building Marketing Strategy, 12th Edition by Delbert Hawkins and David Mothersbaugh

2. Consumer Behavior by Wayne D. Hoyer Deborah J. MacInnis, RikPieters.

3. Consumer Behavior. 10th Edition by Leon Schiffman and Leslie Kanuk.

4. Consumer Behavior 11th Edition by Leon G. Schiffman and Joseph Wisenblit.

5. Social Psychology of Consumer Behavior by MichaelaWanke.

6. Consumer Psychology by CathrineJansson-Boyd. 